University for Business and Technology in Kosovo

UBT Knowledge Center

Oct 28th, 2:00 PM - 3:30 PM

\title{
Web Scrapping and Self Service Business Intelligence: Analysis of Preferences of Tourists in Albania
}

Ardian Hyseni

University of Ljubljana, ah16609@seeu.edu.mk

Follow this and additional works at: https://knowledgecenter.ubt-uni.net/conference

Part of the Databases and Information Systems Commons, and the Information Security Commons

\section{Recommended Citation}

Hyseni, Ardian, "Web Scrapping and Self Service Business Intelligence: Analysis of Preferences of Tourists in Albania" (2017). UBT International Conference. 187.

https://knowledgecenter.ubt-uni.net/conference/2017/all-events/187

This Event is brought to you for free and open access by the Publication and Journals at UBT Knowledge Center. It has been accepted for inclusion in UBT International Conference by an authorized administrator of UBT Knowledge Center. For more information, please contact knowledge.center@ubt-uni.net. 


\title{
Web Scrapping and Self Service Business Intelligence: Analysis of Preferences of Tourists in Albania
}

\author{
Ardian Hyseni \\ Faculty of Economics, University of Ljubljana, \\ Kardeljeva pl. 17, 1000 Ljubljana, Slovenia \\ ah16609@seeu.edu.mk
}

\begin{abstract}
The purpose of this paper is to analyze the preferences of tourists in Albania through the data web scrapped from TripAdvisor.com. Top things to do in Albania, will be analyzed through the comments of tourists in TripAdvisor.com. By using tools for web scrapping and analyzing of data with nVivo and PowerBI, will be analyzed what are the most preferred things to do and what the tourists like doing the most in Albania. This paper will contribute on defining the preferences of tourists in Albania, also can help tourism to invest and attract more tourists in specific areas or improve and invest in places less preferred by tourists.
\end{abstract}

Keywords:Self Service Business Intelligence, Data Analysis, PowerBI

\section{Introduction}

Tourism is a service industry; however, there are continual challenges with service marketing that affect how the tourism product is provided to the tourists. According to (Williams, 2006), tourism and hospitality have become key global economic activities as expectations with regard to our use of leisure time have evolved, attributing greater meaning to our free time[1]. Results in marketing show potentially greater importance in tourism than in other industries but sadly this potential is not always fulfilled [2]. Williams believes that a major reason for such unfulfilled potential lies in most tourism marketing focusing on the destination or outlet in other words the products being offered and lacking focus on the consumer [1].

Therefore, while tourism department decision makers may already use a number of planned marketing activities, this paper claims that they could also exploit the destination image enhancement opportunities that exist through developing an insight about the tourist preferences and delivering the preferred service package to tourists. The growth of socioeconomical life has increased concerns toward recreations, the tourism industry has been developing continually over years. In many countries, the tourism industry is a main industry that deserves our policy attention, and obviously it has become a global socio-economical phenomenon [3]. A successful tourism industry can enhance regional economic development, as well as becoming a source of rich foreign exchange income [4]. The tourism industry is one of the main industries that determine the world's long-term economic growth [5].

\section{Albanian Tourism Industry}

Tourism has become key global economic activity, while the growth in tourism has been impressive, Albania's total global tourism arrivals and earnings are quite insignificant based on 
its potential. Albania has a great potential of tourism, it is located in southeastern Europe's Balkan Peninsula along Adriatic and Ionian coastlines. The country has a rich history with many castles and archeological sites. But yet Albania's most tourism arrivals are from neighboring countries who belong to Albanian ethnicity. Even though Albania it is visited by foreigners yet again this number remains insignificant based on Albania's tourism potential.

The goal of this paper is to analyze tourist preferred destinations. The management of all tourism destinations should focus on enhancing their attractiveness and quality, as well as effectively using the limited resources in current [6]. Therefore, this paper analyses top thirty tourist destinations from the perspective of tourists reviews on TripAdvisor.com. In addition, how these top tourism destinations attract tourists and the tourists' reviews are also included in this paper.

\section{Data Gathering and Data Analysis}

Data were web scrapped from TripAdvisor.com by using tools for web scrapping, and for this paper were chosen the top 30 things to do in Albania. From TripAdvisor.com were web scrapped reviews sorted by country, review title, review comment and date of the review. By using these four elements of the review, with the use of nVivo, were analyzed which are the top words which tourists described the places they visited, and their experience in the places which they visited.

Overall there were 5383 reviews which were web scrapped from top 30 things to do in Albania from TripAdvisor.com. The number of the reviews is enough to give valuable insight for Albanian tourism and its potential from the perspective of tourists.

\section{Results of Tourists Preferences in Albania}

Firstly, after gathering data from TripAdvisor.com, data was imported in PowerBI and analyzed which were the most reviewed places in Albania, than was designed a map of top most visited places based on the number of reviews by attraction and its city in a map provided by PowerBI. 

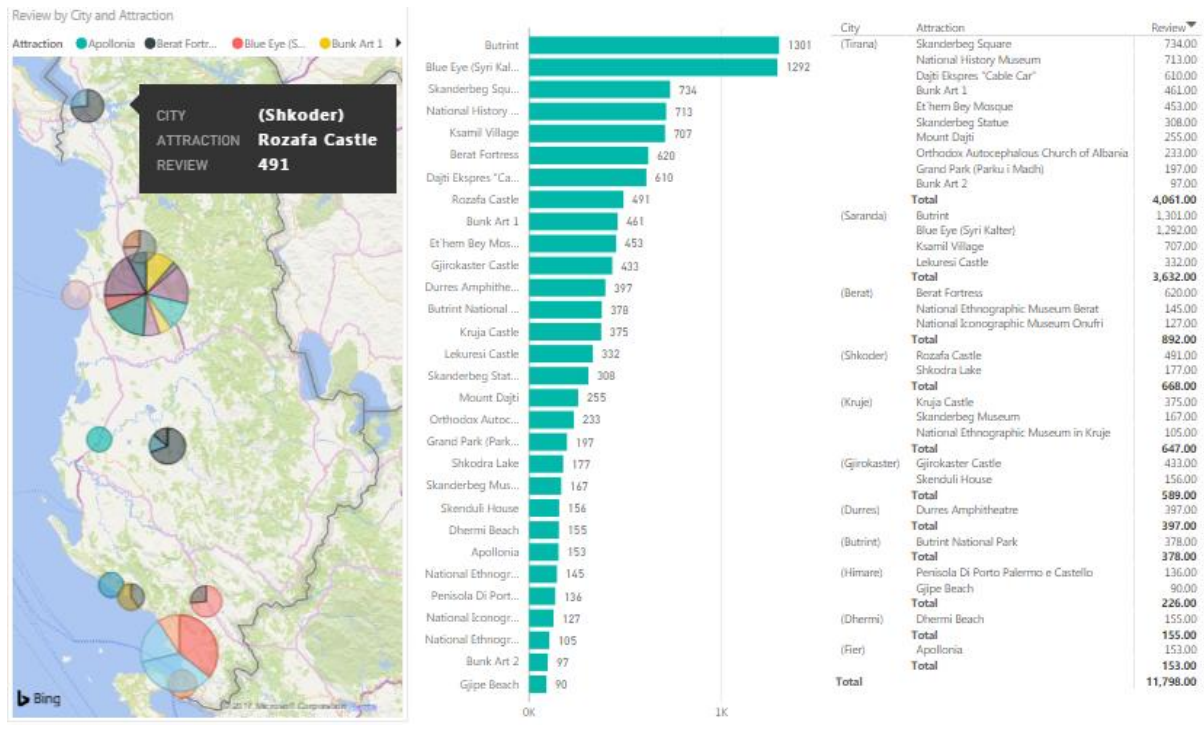

Figure 1. From the left, It shown the map with top 30 things to do in Albania. In the middle is a graph which shows top 0 things to do in Albania from top to bottom based on number of reviews. On the right it is shown a table with details of cities, number of attraction in the city and the reviews.

By using nVivo, the data were analyzed, and the word frequency used on the reviews by tourists gave significant facts that Albania has great potential for development of tourism based on tourists reviews. In Table 1, are shown the most used words and their weighted percentage used by tourists to describe places they visited. 
Table 1. Most used words, number of word used, and weighted percentage from all reviews.

\begin{tabular}{|l|c|c|}
\hline Word & Count & Weighted Percentage (\%) \\
\hline visit & 1599 & 0.90 \\
\hline place & 1550 & 0.87 \\
\hline museum & 1470 & 0.83 \\
\hline castle & 1331 & 0.75 \\
\hline history & 1283 & 0.72 \\
\hline albania & 1279 & 0.72 \\
\hline see & 1279 & 0.72 \\
\hline well & 1172 & 0.66 \\
\hline one & 1118 & 0.63 \\
\hline worth & 1099 & 0.62 \\
\hline nice & 1057 & 0.60 \\
\hline good & 1053 & 0.59 \\
\hline great & 1030 & 0.58 \\
\hline tirana & 962 & 0.54 \\
\hline get & 910 & 0.51 \\
\hline around & 908 & 0.51 \\
\hline city & 898 & 0.51 \\
\hline site & 890 & 0.50 \\
\hline interesting & 871 & 0.49 \\
\hline beautiful & 866 & 0.49 \\
\hline
\end{tabular}

In Figure 2, are shown cloud words of top words used in reviews to describe Albania, and the tourists countries. As it is shown tourists from United Kingdom prefer visiting Albania, or are the largest number who reviewed.

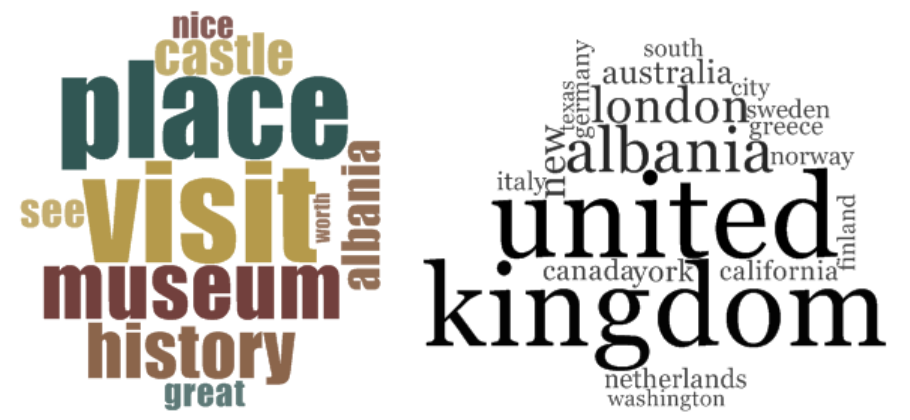

Figure 2. Word cloud of ten most used words in Albania, and top tourists country 
By using nVivo and PowerBI, it was analyzed during which months the reviews were written by tourists, and the results show that Albania has great number of tourists during the summer season, and the most preferred months of tourists are July and August as shown in Figure 2. By analyzing those results, it can be concluded that Albania lacks in winter season tourism or perhaps management of tourism should look for investing on winter season tourism like ski resorts etc. Results show that February, December and January are least preferred months by tourists.

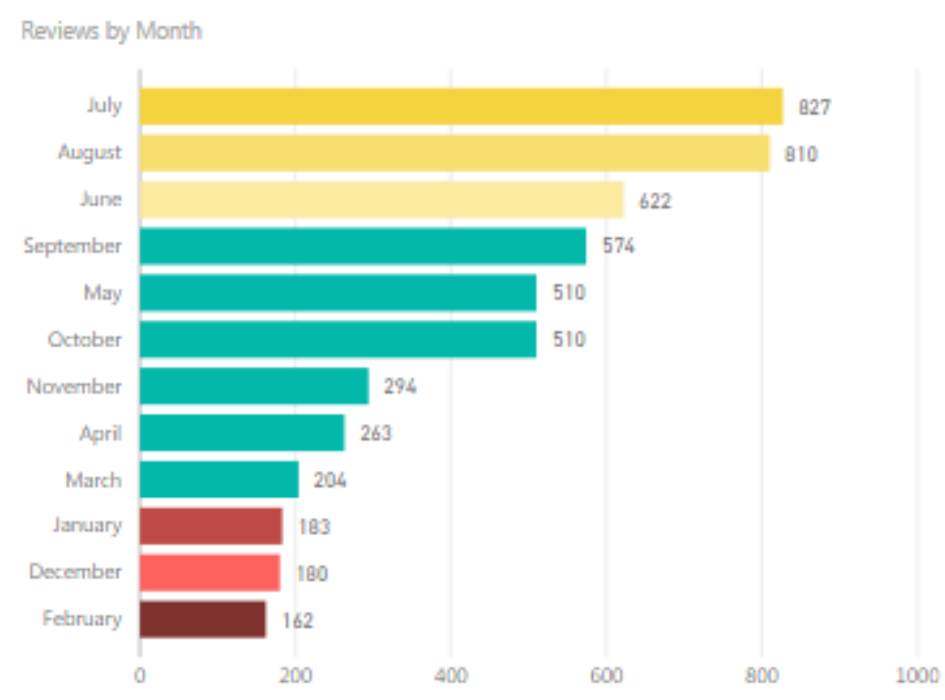

Figure 3. Reviews by month

As shown in Figure 3, the number of tourists who reviewed on TripAdvisor.com has increased significantly over the years, but yet again it can be seen that from year 2014, had great growth but it lacked during the following years. It is clear that Albanian Government or Ministry of Tourism or hospitality and tourism industry, should invest more on tourists by encouraging them to write reviews on Albania's tourism destinations. 


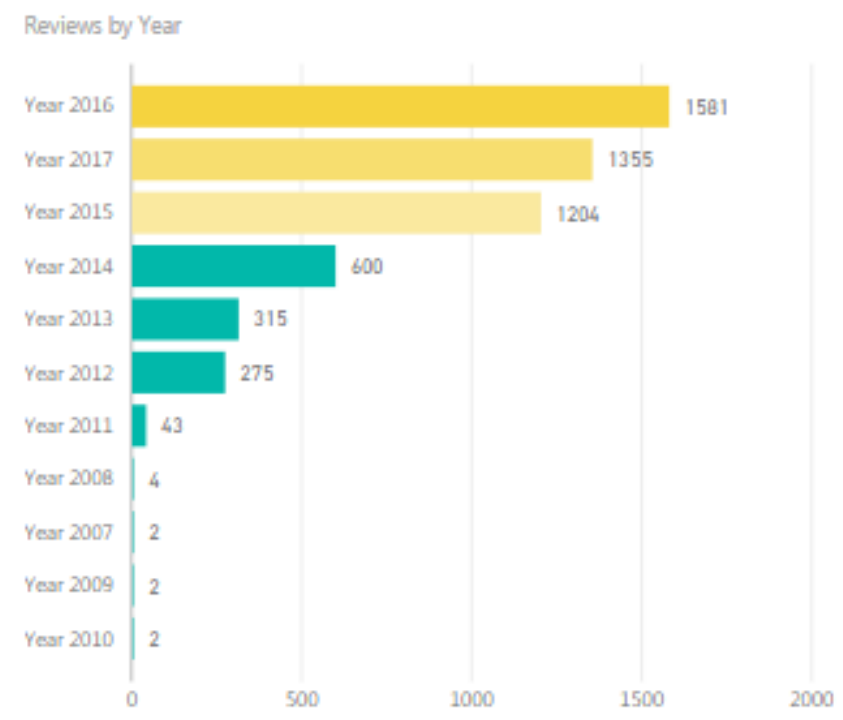

Figure 4. Reviews by Year

\section{Conclusions}

This paper attempts to provide Albanian tourism with valuable information about specific attributes to take into consideration in the tourism services provided to tourists preferences by using tools for data analyses.

This paper has important management implications, this paper can empower the Albania's tourism departments, with information about tourists preferences, so the government and hospitality industry can add value to their relationship with the tourists, by incorporating preferred combination of features. The decision making authorities in the tourism department can use these information provided by the paper, to appropriately bridge the gaps between their perception of value of services provided and the tourists perception of value desired by developing the right improvement action plan. Such improvement actions will ensure greater tourist satisfaction and as well increase competitive advantage to other tourist destinations.

As a conclusion, Albania has great tourism potential, but it needs to invest and improve more on its infrastructure and marketing its tourism potential.

\section{References}

1. Williams, A. "Tourism and hospitality marketing: fantasy, feeling and fun." International Journal of Contemporary Hospitality Management, Vol. 18, 2006: 482-495.

2. Morgan, N. J. and Pritchard, A. Tourism, Promotion \& Power: Creating Images, Creating Identities. 2002: Chichester: Wiley.

3. Cracolici, M.F., Nijkamp, P. "The attractiveness and competitiveness of tourist destinations: A study of Southern Italian regions." Tourism Management 30, 2009: 336344.

4. Wu, W.W., Lan, L.W., Lee, Y.T. "Beyond Travel \& Tourism competitiveness ranking using DEA, GST, ANN, and Borda count." Expert Systems with Applications 38, 2011: 12974-12982 . 
5. Kyriakidis, A., Hancock, H., Oaten, S., Bashir, R. Capturing the visitor economy: A framework for success.In: Blanke, J., Chiesa, T. (eds.) The Travel \& Tourism Competitiveness Report. Geneva, Switzerland: World Economic Forum, 2009.

6. Crouch, G.I., Ritchie, J.R.B. "Tourism, competitiveness, and social prosperity." Journal of Business Research 44, 1999: 137-152. 